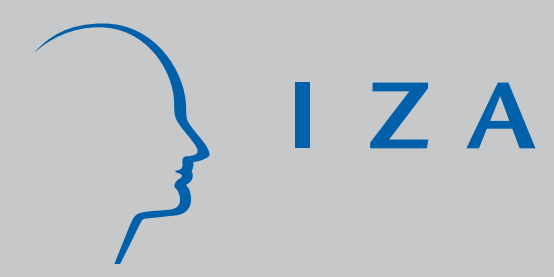

IZA DP No. 2475

Entrepreneurship and the Process of Firms' Entry, Survival and Growth

Enrico Santarelli

Marco Vivarelli

December 2006 


\title{
Entrepreneurship and the Process of Firms' Entry, Survival and Growth
}

\author{
Enrico Santarelli \\ University of Bologna, Max Planck Institute of Economics Jena, \\ ENCORE Amsterdam, and IZA Bonn \\ Marco Vivarelli \\ Università Cattolica Piacenza, CSGR Warwick, \\ Max Planck Institute of Economics Jena, and IZA Bonn
}

\author{
Discussion Paper No. 2475 \\ December 2006
}

\author{
IZA \\ P.O. Box 7240 \\ 53072 Bonn \\ Germany \\ Phone: +49-228-3894-0 \\ Fax: +49-228-3894-180 \\ E-mail: iza@iza.org
}

Any opinions expressed here are those of the author(s) and not those of the institute. Research disseminated by IZA may include views on policy, but the institute itself takes no institutional policy positions.

The Institute for the Study of Labor (IZA) in Bonn is a local and virtual international research center and a place of communication between science, politics and business. IZA is an independent nonprofit company supported by Deutsche Post World Net. The center is associated with the University of Bonn and offers a stimulating research environment through its research networks, research support, and visitors and doctoral programs. IZA engages in (i) original and internationally competitive research in all fields of labor economics, (ii) development of policy concepts, and (iii) dissemination of research results and concepts to the interested public.

IZA Discussion Papers often represent preliminary work and are circulated to encourage discussion. Citation of such a paper should account for its provisional character. A revised version may be available directly from the author. 
IZA Discussion Paper No. 2475

December 2006

\section{ABSTRACT}

\section{Entrepreneurship and the Process of Firms' Entry, Survival and Growth}

This survey paper aims at critically discussing the recent literature on firm formation and survival and the growth of new-born firms. The basic purpose is to single out the microeconomic entrepreneurial foundations of industrial dynamics (entry and exit) and to characterise the founder's ex-ante features in terms of likely ex-post business performance. The main conclusion is that entry of new firms is heterogeneous with innovative entrepreneurs being found together with passive followers, over-optimist gamblers and even escapees from unemployment. Since founders are heterogeneous and may make "entry mistakes", policy incentives should be highly selective, favouring nascent entrepreneurs endowed with progressive motivation and promising predictors of better business performance. This would lead to the least distortion in the post-entry market selection of efficient entrepreneurs.

JEL Classification: L10, M13

Keywords: entrepreneurship, new firm, survival, post-entry performance

Corresponding author:

Marco Vivarelli

Facoltà di Economia

Università Cattolica

Via Emilia Parmense 84

I-29100 Piacenza

Italy

E-mail: marco.vivarelli@unicatt.it 


\section{The aggregate outcomes of industrial dynamics}

At the beginning of the 20th century, Joseph Alois Schumpeter (1908 and 1912) posited the basis for a potential revolution in economics, by showing that the entrepreneur is the underlying force of economic development, i.e. the individual who "on the basis of a stimulus towards a creative function, breaks away from the path of routine" (see Santarelli and Pesciarelli, 1990, p. 694). In spite of Schumpeter's contribution, and although entrepreneurship had already played a role in economic theory since the works of Richard Cantillon and Jean-Baptist Say in the $18^{\text {th }}$ and early $19^{\text {th }}$ century (see Van Praag, 1999), the entrepreneurial function has only in the last few years been systematically proposed as an additional factor in explaining economic growth within developed countries. While endogenous growth theories (see Lucas, 1988; Romer, 1986 and 1990; Grossman and Helpman, 1991) highlighted the important role of human capital and R\&D as additional explanations of increasing returns in the aggregate production function, various scholars have recently put forward entrepreneurship as a third component of a new "new-growth theory”, exploiting the opportunities provided by new knowledge and ideas that are not fully commercialized by incumbent firms (see Acs et al., 2005; Henrekson, 2005; Audretsch, Keilbach and Lehmann, 2006). According to these authors, by serving as a conduit for both entirely new knowledge and knowledge spillovers, entrepreneurship is the missing link between investment in new knowledge and economic growth ${ }^{1}$.

But what is entrepreneurship? In the industrial organization literature the answer is unequivocal: the process by which new enterprises are founded and become viable. In this connection, the most common way of measuring it is to look at new firm formation, that is, at entry rates (either gross or net). For instance, according to OECD (2003), industrial dynamics, i.e. the entry and exit of firms, would account for between 20 and 40 per cent of

\footnotetext{
${ }^{1}$ According to Audretsch and Thurik (2004), and Carree and Thurik (2006) there are three channels by means of which entrepreneurship may positively affect economic growth: increasing innovation and knowledge spillovers, increasing competition, and increasing diversity in sectors and firms.
} 
total productivity growth in eight selected OECD countries (see also Audretsch and Keilbach, 2004a), therefore supporting the idea that entrepreneurs are among the driving forces of economic growth and structural change.

However, an entrepreneur is not just a do-it-yourselfer, a simple company founder, but an individual who may be described using adjectives such as "innovative, flexible, dynamic, risk-taking, creative, and growth-oriented” (see Stevenson and Gumpert, 1985). The idea is therefore that new entrants can displace obsolescent firms in a process of "creative destruction” (see Schumpeter, 1934 and 1943; for an account in an endogenous growth framework, see Aghion and Howitt, 1992) which may be considered an important microdeterminant of economic growth. From such a perspective, entrepreneurs are those individuals Schumpeter labelled “energetic types” who display their “essential features” by introducing the "new" into various activities and by "breaking with the established routines" usually adhered to by managers (see Santarelli, 2006a, p. xii). Thus, entrepreneurship deals with the role of risk takers and creative individuals who start a new business or revive an already existing one (see Hébert and Link, 1999)².

In more general terms, it has been argued that new firm formation can be beneficial for economic growth (at least in developed countries, see Van Stel, Carree and Thurik, 2005), employment generation and unemployment reduction (see Hart and Oulton, 2001; Thurik, 2003; Baptista, Van Stel and Thurik, 2006).

It has long been observed that entrepreneurial activity varies across geographic space. Thus, all the positive effects of entrepreneurship and new firm start-ups underlined above would be particularly obvious at the regional level (see Lee, Florida and Acs, 2004) where it has been found that interspatial variations in the endowment of "entrepreneurship capital" may be an important determinant of differences in regional output, knowledge spillovers and productivity (see Audretsch and Keilbach, 2004b; Varga and Schalk, 2004).

\footnotetext{
${ }^{2}$ Other measures of the overall entrepreneurial dynamics widely used in empirical studies include business ownership, small business share, "nascent entrepreneurship” (see Gelderen, Thurik and Bosma, 2006 and Johnson, Parker and Wijbenga, 2006) and the preference for entrepreneurship (i.e. latent entrepreneurship). Recent studies have identified a U-shaped relationship between a country's rate of entrepreneurial activity and its level of economic development (see Wennekers et al., 2005).
} 
However, empirical macroeconomic evidence also casts great doubt on the progressive potentialities of new firm formation and business start-ups.

First, survival rates of new firms are strikingly low: according to Bartelsman, Scarpetta and Schivardi (2005), who worked on data for ten OECD countries, about 20-40 per cent of entering firms fail within the first two years of life, while only 40 to 50 per cent survive beyond the seventh year (OECD, 2003, p. 145). In a previous paper with David Audretsch (Audretsch, Santarelli and Vivarelli, 1999a), we studied 1,570 new Italian manufacturing firms $^{3}$ and tracked their post-entry evolution for six years. We found that hazard rates increased markedly during the first two years and then tended to decrease, with a final survival rate after 6 years of activity equal to $59.1 \%$.

Second, entry and exit rates are significantly correlated and this is one uncontroversial "stylized fact" of the entry process according to Geroski (1995, p. 424), who pointed out that the "mechanism of displacement, which seems to be the most palpable consequence of entry, affect young, new firms more severely” (see also Baldwin and Gorecki, 1987 and 1991). The empirical evidence has confirmed that entry and exit rates are positively correlated across industries in different OECD countries (see Bartelsman, Scarpetta and Schivardi, 2005).

This macroeconomic evidence opens the way to important considerations about the alleged role of entry as a vehicle for technological upgrading, productivity growth and employment generation. In fact, if entry were driven mainly by technological opportunities, growing sales and profit expectations, one should observe a negative crosssectional correlation between entry and exit rates, in particular over short time intervals. On the contrary, entry and exit rates are positively and significantly correlated and market “churning” emerges as a common feature of industrial dynamics across different sectors and different countries. In other words, many sectors are characterised by a fringe of firms operating at a suboptimal scale where the likelihood of survival is particularly low and where "revolving door" firms are continuously entering and exiting the market.

\footnotetext{
${ }^{3}$ We used data from the National Institute for Social Security (INPS), identifying all new firms - with at least one employee - founded in January 1987 and tracking them at monthly intervals until January 1993.
} 
Accordingly, industry-specific characteristics, such as scale economies and the endowment of innovative capabilities (see Audretsch, 1991 and Agarwal and Audretsch 2001), exert a significant impact on entry, exit, and the likelihood of survival of newborn firms. For example, in industries characterized by higher minimum efficient scale (MES) levels of output, smaller firms face higher costs that are likely to push them out of the market within a short period after start-up (see Lotti and Santarelli, 2004). Therefore, in many sectors new firm start-ups may simply originate what has correctly been called "turbulence" (a term first introduced by Beesley and Hamilton, 1984; see also Caves, $1998^{4}$ ).

Obviously, new firm formation may be more or less conducive to technological change and economic growth according to the different sectors in which it occurs. For instance, "new technology-based firms” (NTBFs; see Acs and Audretsch, 1990; Colombo, Delmastro and Grilli, 2004) in advanced manufacturing and ICT services surely play a different role compared with small-sized start-ups in traditional sectors ${ }^{5}$. Therefore, in some sectors the “creative destruction" role of new firm formation may be dominant compared with simple "turbulence”, while the opposite may hold in other sectors.

However, Schumpeter (1934) informs us that the entry of new firms is due to a large majority of "imitators" and a tiny minority of leaders (innovators). According to Baumol (2005), “replicative” entrepreneurs are those who start a firm similar to previously-started businesses. Irrespective of whether imitators start their business when they hear about the existence of the early entrant or once the perceived gain from starting-up exceeds a given threshold determined by their prior beliefs (Young, 2006), one has to recognize that when dealing with gross entry across all economic sectors we encounter a huge multitude of “followers” and very few 'real' entrepreneurs (innovators).

\footnotetext{
${ }^{4}$ In a recent paper, Baptista and Karaöz (2006) study the determinants of turbulence at the six digit industry level in Portuguese manufacturing over the 1986-1993 period.

${ }^{5}$ However, even in the innovative sectors the degree of uncertainty inherent in new knowledge dictates that only those new firms that prove to be viable grow rapidly, while other attempts that turn out not to be viable stagnate and may ultimately exit (see Audretsch and Thurik, 2000).
} 
These considerations make it extremely interesting to look at the microeconomic variety characterising new entrants ${ }^{6}$. As in many other fields of industrial organization literature, “heterogeneity” (see Dosi, 1988; Dosi et al., 1995) is a crucial feature in explaining the start-up of new firms, their extremely diverse chances of survival and their very different post-entry performances.

The purpose of this paper is to provide a contribution to the identification of the role of entrepreneurship in economic growth by mapping out the different microeconomic determinants of new firm formation, the relationship between ex-ante characteristics (of the founder) and post-entry performance (of the new firm), and possible scope for economic policy addressed at singling out "entrepreneurship” from market "churning” and "turbulence". Although "entry" and "entrepreneurship" are obviously related topics, the focus of what follows will be on the latter. In particular, attention will be concentrated on the microeconomic and individual determinants of new firm formation rather than on the sectoral characteristics and consequences of entry and exit processes. As better clarified at the beginning of the following section, in the rest of the paper we will look at the investigated issues at the level of the single firms, while the industrial and macroeconomic scenarios will remain in the background ${ }^{7}$.

Accordingly, in the following three sections we will discuss: 1) the determinants of the foundation of a new firm; 2) the patterns of learning, survival and growth of newborn firms and possible links between ex-ante entrepreneurial features and post-entry performance; 3) possible policy implications.

\footnotetext{
${ }^{6}$ See also Vivarelli (2006), chap. 1.

${ }^{7}$ Accordingly, it is beyond the scope of this paper to fully account for the vast economic literature about entry and exit and their consequences on market structure.
} 


\section{From macroeconomic outcomes to microfoundations of new firm formation}

The literature in industrial organization has devoted much attention to the study of the entry process and its determinants. In the textbook view originally put forward by Mansfield (1962), a queue of well-informed potential entrepreneurs is supposed to be waiting outside the market, and the expected level of profit is considered the "trigger" factor determining entry, once barriers to entry have been taken into account (see also Orr, 1974; Khemani and Shapiro, 1986).

According to more recent studies in this stream of literature, new firm formation may be triggered not only by profit expectations, but also by favourable economic conditions such as economic growth and high innovative potential, while hindered by both exogenous and “endogenous barriers to entry” such as advertising expenditure (see; Acs and Audretsch, 1989a and 1989b; Geroski and Schwalbach, 1991; Arauzo-Carod and Segarra-Blasco, 2005).

However, the industrial organization approach focuses on the market mechanism and may obscure the decision-making process at the level of the individual ${ }^{8}$ (see Winter, 1991), thus underestimating the factors behind the entrepreneur's motivation in starting a new business. Indeed, in the $20^{\text {th }}$ century authors like Knight (1921), Schumpeter (1934) and Oxenfeldt (1943) drew attention to the subjective features of the actual founder of a new firm. Following their contributions, we are aware that important individual determinants may act as "push factors" and be related both to environmental characteristics and to the potential founder's personal characteristics.

\footnotetext{
${ }^{8}$ In this "ecological” approach, entrepreneurship is generally measured as the number of new firms relative to the size of the existing population of businesses in a given industry (see Acs, 2006). In contrast, if the individual "push factors" are fully taken into account, new firms are related to the labour force (for further discussion, see Santarelli, Carree and Verheul, 2006; and Vivarelli, 2006).
} 
For instance, the specific local/sectoral labour market plays an important role because the vast majority of new founders - about two/thirds - come from the same geographical area and the same sector in which they were previously employed/located, the rest being young people at their first job experience, previously ceased entrepreneurs and founders moving from an outside region (see Cooper, Woo and Dunkelberg, 1989; Vivarelli, 1991; Garofoli, 1994; Storey, 1994; Cressy, 1996; Arrighetti and Vivarelli, 1999; Shane, 2000; Klepper, 2001; Helfat and Lieberman, 2002). Individuals starting a new firm in the same sector and the same region where they were previously employed/located are more likely to be characterized by a deeper understanding of firm organization in that specific sector and of the inner and 'relational' features of the business environment in which the new firm will operate (Storey, 1994) ${ }^{9}$. Indeed, in a recent paper, Michelacci and Silva (2005) found that the fraction of entrepreneurs who set up their businesses in the location where they were born was significantly higher than the corresponding share for dependent workers and more importantly - that firms created by locals were bigger, more valuable, more capital intensive and better financed than their counterparts created by non-locals. The authors interpreted their findings by arguing that local entrepreneurs can - on average - better exploit the economic and financial opportunities available in the region where they were born $^{10}$.

In this framework, new firm formation can be modelled as a "self-employment" choice based on the comparison between the wage earned in the previous job and the expected profit as an entrepreneur (see Creedy and Johnson, 1983; Vivarelli, 1991; Audretsch, 1995; Foti and Vivarelli, 1994; Geroski, 1995; Reynolds, 1997; Vivarelli, 2004). Contrary to the textbook approach, in self-employment theory the foundation of a new firm is therefore not

\footnotetext{
${ }^{9}$ As a matter of fact, what the founder of a new firm knows and can do is related to what (s)he learned in the organization by which (s)he was formerly employed (Cooper 1985; Colombo and Grilli, 2005).

${ }^{10}$ This finding is consistent with the hypothesis put forward by Fujita and Thisse (2002), who identified the centripetal effect exerted by localized positive externalities as one of the main factors producing the economic landscapes where agglomeration of economic activities is determined.
} 
fostered by absolute profitability, but by the difference between expected profits and current local wages in the same sector on the one hand, and the degree of risk aversion and the differences in risk of the two occupational alternatives on the other (Kihlstrom and Laffont, 1979; Parker, 1996 and 1997; Grilo and Thurik, 2006, Cressy, 2006.) ${ }^{11}$. This means that entry may have a counter-cyclical component and may well be induced by industrial restructuring and decreasing real wages rather than by buoyant demand expectations and an appropriate endowment of entrepreneurial capabilities (see Highfield and Smiley, 1987; Hamilton, 1989). For instance, Foti and Vivarelli (1994) found a confirmation of the "self employment" model showing that entry rates ${ }^{12}$ were significantly correlated with the income gap between expected profits and current wages.

Similarly, founding a new firm may be an alternative to uncertain future career prospects or even an “escape from unemployment” (see Oxenfeldt, 1943; Evans and Leighton, 1990; Storey, 1991 and 1994). The empirical evidence suggesting the important role of job losses in fostering entry is indeed quite robust (see Storey and Jones, 1987; Santarelli, Carree and Verheul, 2006). Using a panel of Italian data ${ }^{13}$, Audretsch and Vivarelli (1995 and 1996a) found that job losses are an important "push factor" in spurring new firm formation at the regional level (together with other factors such as the local industrial structure and the presence of agglomeration and external economies).

While unemployment is rarely the main driver of new firm formation, it often plays a role, which for certain countries has proved to be particularly significant during economic downturns. For instance, at the end of the ' 90 s, in the UK the incidence of people starting a firm not because of a market opportunity but just because they had no better choice was about 22\% (see Small Business Service, 2001, p.6). In previous studies by one of the

${ }^{11}$ Whether entrepreneurs are more likely to engage in risky behaviour (see Palich and Bagby, 1995) is a controversial issue and empirical evidence is inconclusive. For example, in a recent paper, Norton and Moore (2006) conclude that entrepreneurs do not differ from non-entrepreneurs as regards their risk-taking propensity.

12 Defined as the ratio between new firms, with at least one employee, and resident population in different Italian regions over the period 1985-88.

${ }^{13}$ The database used is the one defined in the previous footnote. 
authors (Vivarelli and Audretsch, 1998; Arrighetti and Vivarelli, 1999; Vivarelli, 2004) using different Italian datasets ${ }^{14}$, the state of actual unemployment or an impending state of unemployment was never a top crucial motivation in determining the decision to start a new business. However, although rather low in the average rankings, the motivation “escape from unemployment” emerged as being quite important in about 15-20\% of the examined cases. Likewise, unemployment has been found to be one of the most important determinants of "latent" entrepreneurship in the stagnating Japanese economy of the second half of the '90s (see Masuda, 2006).

Thus, entry may be determined by a set of different factors among which one can find some "progressive" determinants such as favourable economic perspectives and promising technological opportunities, but also "regressive" determinants such as low wages and the actual condition of being (or the fear of becoming) unemployed.

In addition, founders differ with regard to personal characteristics such as previous work experience, family tradition, financial status, age, gender, education, motivations. For example, the founder of a new firm is heavily influenced by his/her own background, with particular reference to his/her previous job experience (see Storey, 1982; Johnson, 1986; Bates, 1990; Reynolds et al., 2001). Among the personal characteristics of the founder, family background is also singled out as a key factor by econometric estimates which explain new firm formation as an act of self-employment (see Evans and Leighton, 1989; De Wit and Van Winden, 1989; Blanchflower and Oswald, 1998; Hout and Rosen, 2000; Reynolds et al., 2001). For instance, in a very recent paper Burke, FitzRoy and Nolan (2006) studied a cohort of British individuals born in March 1958, discovering that selfemployed fathers - as well as fathers who are managers of small firms - tend to encourage entrepreneurship among their sons and daughters.

\footnotetext{
${ }^{14}$ Vivarelli and Audretsch (1998) studied 100 new firms in the Emilia region on the basis of a questionnaire survey conducted in 1993; Arrighetti and Vivarelli (1999) used a database of 147 new manufacturing firms originating from spin-offs in the Milano province on the basis of returned questionnaires collected in 1996; Vivarelli (2004) examined 365 potential founders in the Milano province through a questionnaire survey developed in the year 1999.
} 
An important stream of literature has investigated the impact of financial constraints on business start-ups, mostly bringing the tradition initiated by Fazzari, Hubbard and Petersen (1988) in their seminal study on the effect of cash flow on investment into the field of small business economics. For instance, Evans and Jovanovic (1989) found that the initial level of assets strongly influences the probability of self-employment (see also Blanchflower and Osvald, 1998; Cabral and Mata, 2003; Hurst and Lusardi, 2004; Kan and Tsai, 2006). Other studies have examined the probability of transition to self-employment after an unexpected financial gain, such as a lottery prize, a windfall gain or a job bonus. Interestingly, these studies almost invariably found that the exogenous arrival of new financial resources increased the probability of starting up a company (see Holtz-Eakin, Joulfaian and Rosen, 1994; Lindh and Ohlsson, 1996; Taylor, 1999). However, the fact that wealth, inheritance and windfall gains spur entrepreneurship does not necessarily imply that business start-ups are inherently credit rationed (see Levenson and Willard, 2000 and Parker, 2002 and 2004). For instance, Parker and Van Praag (2004), using Dutch data from the mid-1990s, found that only one fifth of new founders obtained less finance than they required.

Other studies show that non-economic factors may turn out to be even more important than variables such as profit expectations, entry barriers, local labour and capital markets. For instance, the potential entrepreneur seems to be strongly influenced by particular psychological attitudes such as the desire to be independent, the search for autonomy in the workplace, aspiration to full exploitation of previous job experience and acquired ability, the desire to be socially useful and to acquire improved social status (see Creedy and Johnson, 1983; Evans and Leighton, 1990; Blanchflower and Meyer, 1994; Blanchflower and Osvald, 1998; Vivarelli 1991 and 2004). With regard to social status, entrepreneurship as a sign of self-sufficiency and individualism has been traditionally highly valued in the U.S. (see Zacharakis, Bygrave and Shepherd, 2000, p.14), but it is increasingly appreciated in European countries as well, including the ex-communist nations (see Minniti and Venturelli, 2000; Grilo and Thurik, 2006). Questionnaire analyses conducted by one of the authors (Vivarelli and Audretsch, 1998, p. 492; Arrighetti and Vivarelli, 1999, p. 933; Vivarelli, 2004, p. $44^{15}$ ) invariably show that the search for independence and the desire to

\footnotetext{
${ }^{15}$ See previous footnote.
} 
fully exploit his/her own skills are ranked first among the determinants of new firm formation. On the other hand, textbook determinants such as profit expectations and the search for a market niche turn out to be important, but ranked below the personal/psychological motivations. Interestingly enough, innovation is always lagging behind, with a minority of firms (about 15-20\%) indicating the desire to introduce product and/or process innovation as a fundamental reason to start a new independent economic activity.

Hence, the overall rate of new firm formation is actually an aggregate indicator which puts together very heterogeneous initiatives characterized by different motivations and chances of survival. In this context, it is not surprising that new firms exhibit a very high rate of early failure at the aggregate level (see previous section). The econometric evidence at the sectoral and microeconomic levels is largely consistent with this outcome: studies on different countries and different sectors reveal that more than $50 \%$ of new firms exit the market within the first five years of activity (see Dunne, Roberts and Samuelson, 1988 and 1989; Reid 1991; Geroski, 1995; Mata, Portugal and Guimaraes, 1995; Audretsch and Mahmood, 1995; Audretsch, Santarelli and Vivarelli, 1999a; Johnson, 2005).

Since new firms are based both on progressive and regressive push factors and entrepreneurs are very heterogeneous as far as their motivations, capabilities and aptitude for innovation are concerned, some new initiatives survive and grow, while others are subject to a "revolving door" mechanism" ${ }^{16}$.

Consistently with this evidence, one may hypothesise that some of the observed entries are simply due to "entry mistakes” (see Cabral, 1997; Geroski and Mazzucato, 2001), thus causing turbulence, whereas a true Schumpeterian displacement-replacement effect (“creative destruction”) can be detected only in a minority of cases. While entry mistakes conflict with a conventional approach in which potential entrants are driven by rational

\footnotetext{
${ }^{16}$ In particular, as far as the aptitude for innovation is concerned, the rate of innovation is constrained by the ability of agents to exploit certain notional innovative opportunities, which are usually well in excess of what a founder of a new firm is able to master (Chiaromonte and Dosi, 1993).
} 
expectations based on expected profits ${ }^{17}$, they can be understood more easily when bounded and procedural rationality is assumed (see Simon, 1982; Heiner, 1983; Dosi and Egidi, 1991) ${ }^{18}$. Accordingly, potential entrepreneurs may well be affected by “overconfidence”, generating excess of entry, which in turn leads to infant mortality and entrepreneurial disillusion (see Dosi and Lovallo, 1998; for an experimental economics exercise see Camerer and Lovallo, 1999). Parker (2006) discusses both the psychology literature that gives reasons for expecting entrepreneurs to be especially prone to unrealistic over-optimism and previous empirical evidence showing that optimism is significantly and positively associated with the propensity to be an entrepreneur (see De Meza, 2002; Åstebro, 2003; Coelho, de Meza and Reyniers, 2004).

If one takes into account the (often dominant) psychological attitudes mentioned above (desire to be independent, fear of becoming unemployed, frustration in previous job) entry mistakes and excess entry can be further justified. In fact, the observed occurrence of these entry mistakes suggests a kind of attitude which can be defined as a "try and see" bet. In

${ }^{17}$ However, some theoretical models of entry such as those proposed by Jovanovic (1982) and Hopenhayn (1992) managed to combine maximising behaviour with the occurrence of “entry mistakes” which can later be detected by rational learning processes (see Section 3 below).

${ }^{18}$ A detailed comparison of different theories of entrepreneurship is beyond the scope of this paper (for a historical survey, see Endres and Woods, 2006). Here it is sufficient to say that entry mistakes are unthinkable within the neoclassical theory of entry where potential entrepreneurs have equal access to the same information and technology and are always and everywhere maximizers. In contrast, entry mistakes are conceivable within the “Austrian” approach (see Kirzner, 1973 and 1995) where profit opportunities are not likely to be recognized by all the potential entrepreneurs, but only by the "alerted" ones that are able to recognise latent, overlooked opportunities. Finally, entry mistakes are perfectly endogenised within the behavioural framework, where the potential entrepreneur is endowed with an ordinary human mind characterised by an information set and a cognitive capability substantially different from those attributable to an optimizing entrepreneur (see Simon, 1987, p. 267). 
this view, new founders - mainly driven by a personal search for autonomy and job satisfaction - "visit" a sectoral niche searching for business chances; later, they discover whether their entry decision was right or wrong and may decide to exit. Accordingly, market churning, turbulence and early failure should be considered as normal features of industrial dynamics or even a necessary price to pay in order to allow "exploration" of new technological and entrepreneurial possibilities (according to Dosi and Lovallo, 1998, pp. 57 and ff., entry mistakes and early failures at the microeconomic level may be consistent with increasing social benefit at the aggregate level).

On the whole, the Schumpeterian hypothesis of creative destruction and replacement of old, unproductive firms by new and innovative ones has been challenged by the theory and the evidence in favour of the "churning" hypothesis of entry mistakes and turbulence (for an interesting discussion on the alternative implications of the two models, see ManjónAntolín, 2004).

These findings lead to the conclusion that several heterogeneous entry processes are simultaneously at play in the economy and that real entrepreneurs bringing about innovation and economic growth should be distinguished from "revolving door" firms causing sub-optimality, early failures, and precarious and temporary job creation.

Together with this great heterogeneity as regards individual founders, sectoral variety should also be taken into account carefully. Indeed, patterns of entry may differ in different industrial sectors both with regard to the weight of "revolving door" firms (for example, entry mistakes should be less frequent in sectors characterised by higher sunk costs: see Sutton, 1991 and 1997; Cabral 1995 and 1997; Audretsch, Santarelli and Vivarelli, 1999a) $)^{19}$ and with regard to the relative importance of the different determinants of a firm's foundation (for instance, a progressive innovative aptitude may be dominant in fostering

${ }^{19}$ On the other hand, according to Audretsch (1995), industries characterized by scale economies are better represented by the revolving door metaphor, while the Marshallian metaphor of the "forest" (new entries can force incumbents to exit via displacement, see Marshall, 1961) applies to the industries in which small firms tend to have the innovative advantage. 
entry in the "science based sectors", but not so crucial in traditional manufacturing and low-tech service sectors: see Pavitt, 1984; Audretsch, 1991; Piergiovanni and Santarelli, 1995; Breschi, Malerba and Orsenigo, 2000; Marsili, 2002; Piergiovanni et al., 2003).

Finally, the presence of substantially different geographical environments further increases the variability in the determinants and post-entry impact of new firm formation. In fact, the theoretical and empirical literature in regional economics points to the importance of progressive and regressive factors such as local industrial restructuring, unemployment, demand growth, agglomeration economies, availability of financial resources in fostering new firm formation at the local level (see Armington and Acs, 2002; Shane 2003). On the same ground, a local economy composed mainly of small-sized firms may be seen as an incubator of new entrepreneurs (see Cathcart and Johnson, 1979; Storey, 1982; Johnson, 1983; Storey and Johnson, 1987; Storey, 1994), but may well also cause excessive entry, early failures and turbulence.

As far as the progressive and locally-bounded determinants of new firm formation are concerned, interesting developments in the literature point to the existence of local spillovers of non-tradable knowledge (see Audretsch and Feldman, 1996; Audretsch and Vivarelli, 1996b; Audretsch and Feldman, 2004; Globerman, et. al. 2005). In this view, the availability of a pool of workers with industry-specific skills that embody high-level human capital and informational spillovers are a valuable support for clustered start-ups, as opposed to isolated producers. Firm formation - especially in high-tech sectors - is therefore hypothesized as being spurred by industry density and industrial specialization (see Krugman, 1991, Audretsch and Vivarelli, 1995 and 1996a; Armington and Acs, 2002).

Obviously, and in accordance with what has been discussed above, different regional determinants such as economic growth and knowledge spillovers on the one hand, and unemployment rates and restructuring of local companies on the other, may play opposite roles in favouring the start-up of either "revolving door" firms (merely increasing local turbulence) or promising enterprises (fostering local economic growth).

All in all, individual, sectoral and geographical heterogeneities do not permit the treatment of new firm formation as a "unicum" and make it impossible to use entry and entrepreneurship as synonyms. Moreover, since new firm formation is an aggregate where 
innovators and escapers from unemployment, rational entrepreneurs and over-optimists, experienced and committed founders and "try and see” gamblers are all mixed up together, post-entry performance of newborn firms may vary greatly (see also Santarelli and Vivarelli, 2002) $)^{20}$. As a consequence, the observed positive macroeconomic impact discussed in the previous section is affected by a compositional effect which has to be taken into account. With this purpose in mind, a discussion of the post-entry evolution of newborn firms is merited.

\section{Heterogeneous entrants are leading to very divergent post-entry performances}

From a theoretical point of view, Lucas (1978) put forward the first theory of the size distribution of firms based on the relative endowment of entrepreneurial talents ${ }^{21}$. However, the first author to represent the post-entry evolution of newborn firms formally was Boyan Jovanovic in his celebrated contribution in Econometrica (1982). Jovanovic proposed a Bayesian model of noisy selection, according to which efficient firms grow and survive, whereas inefficient ones decline and fail. In particular, in Jovanovic's model of passive learning, firms are initially endowed with unknown, time-invariant characteristics

${ }^{20}$ To give an extreme example, imagine the substantially different likelihoods of survival and satisfactory post-entry performance of a firm founded by an unemployed non-local individual, with little job experience, no family entrepreneurial tradition and affected by credit constraints, in comparison with a newborn firm funded by a rational and innovative local entrepreneur with no financial constraints and former managerial experience in a local incumbent firm within the same industrial sector.

${ }^{21}$ For a recent extension of Lucas' model incorporating the possibility that entrepreneurial talents may be acquired by watching other entrepreneurs already active in the market, see Guiso and Schivardi (2005). 
(i.e. ex-ante efficiency parameters); ex-post the prior distribution is updated as evidence comes in and some entrepreneurs discover that they are more efficient than others. Thus, in any period each firm has to decide its strategy: whether to exit, continue at the same size, grow in size, or reduce its productive capacity ${ }^{22}$.

One can easily see that Jovanovic's model is perfectly consistent with a world where founders are quite heterogeneous in terms of both general and specific characteristics, entry mistakes can easily occur, entry can be originated by a "try and see" bet and early failures are rather common (see previous section; see also Lotti and Santarelli, 2004). The same line of argument applies to more recent models of active learning. While Hopenhayn (1992) first introduced innovation as an exogenous process, Ericson and Pakes (1995) assumed that all the decisions taken by firms were meant to maximize the expected discounted value of the future net cash flow, conditional on the current information set. In their model, a firm knows its own characteristics and those of its competitors, along with the future distribution of industry structure, conditional on the current structure. Jovanovic's assumptions concerning small industry size and product homogeneity are relaxed in Ericson and Pakes' model, in which new entries may either adjust in size to the MES level of output of the "core" of the industry or choose/find a niche within which the likelihood of survival is relatively high even though the firm does not grow fast. In a subsequent work, Pakes and Ericson (1998) examined two cohorts of firms from Wisconsin in the retail and the manufacturing industries, and found that the structure of the former industry was compatible with Jovanovic's passive learning model, while that of the latter was compatible with their model of active exploration. In both models optimal behaviour generates a set of 'stopping states' which can imply early exit from the market. Characterised by either passive or active learning, founders in these theoretical models are heterogeneous as far as their capabilities and beliefs are concerned, and committed to recursive decisions where early exit is always an available and rational option. Either

\footnotetext{
${ }^{22}$ In Jovanovic’s model newborn entrepreneurs behave as rational Bayesian learners and so it may well happen that they rationally but mistakenly exit as a result of unlucky and unrepresentative feedbacks on their ability from the market. Under the assumption that feedbacks are normally distributed, the likelihood of this happening should be relatively small (the authors thank one of the referees for raising this useful comment).
} 
because of entry mistakes or learning failure or wrong differentiating strategies, newborn firms may cease in the early phases of their life cycles.

From an empirical perspective, a recent stream of literature has focused on the post-entry performance of firms and has investigated survival, growth and early exit of newborn firms (see, for instance, Reid, 1991; Boeri and Cramer, 1992; Baldwin and Rafiquzzaman, 1995). Within this field, it is possible to analyse the relationship between ex-ante features of entry, survival and, in the case of survival, post-entry performance of newborn firms, which can be measured in terms of employment growth, profitability or market penetration.

For instance, some of these studies have discovered a positive relationship between startup size and survival (see Audretsch and Mahmood, 1995; Mata, Portugal and Guimaraes, 1995; for more controversial results, see Audretsch, Santarelli and Vivarelli, 1999a; and Agarval and Audretsch, 2001). Others have found a negative relationship between start-up size and post-entry growth, thus rejecting Gibrat's Law (see Gibrat, 1931; Hall, 1987; Evans, 1987; Dunne and Hughes, 1994; Hart and Oulton, 1996; Sutton, 1997; Lotti, Santarelli and Vivarelli, 2001 and 2003). In contrast, smaller entrants with a sub-optimal size are at high risk of early failure and they must grow in order to survive the stringent market selection in operation. From an empirical point of view, this means that smaller entrants should be characterised by both higher failure rates and higher growth rates (conditional on survival), as found in the previously cited studies.

However, entry size does not always emerge as a good predictor of survival. For instance, in a couple of studies we conducted together with David Audretsch (see Audretsch, Santarelli and Vivarelli,1999a and $1999 b^{23}$ ), we found that start-up size was positively correlated with survival in nine industrial sectors out of thirteen and barely significant ( $90 \%$ of confidence) only in three sectors ${ }^{24}$. A possible interpretation for these results - at least in some situations such as Italian manufacturing where small and microfirms are dominating - is that virtually all new firms enter the markets well below the MES and so

\footnotetext{
${ }^{23}$ For details about the data used, refer to footnote 3.

${ }^{24}$ Robust results were found both through survival logit estimates over the examined sixyear period and through tobit duration estimates, with duration measured in months.
} 
entry size becomes less informative about the possible chances of survival ${ }^{25}$. By the same token, in a previous study by one of the authors - dealing with the post-entry performance of new-born firms in the financial intermediation services - it was found that in local markets in which large-scale incumbents have a larger market share, the likelihood of survival of new entrants tends in general to be lower, irrespective of their initial size (Santarelli, 2000).

In contrast, credit constraints and lack of financial capital in general should limit both the likelihood of survival and the rate of growth of newborn firms (see $\mathrm{Xu}, 1998$; Carpenter and Petersen, 2002; Becchetti and Trovato, 2002), in accordance with the empirical literature providing evidence that smaller firms are financially constrained by comparison with their larger counterparts (see Binks and Ennew, 1996; Fagiolo and Luzzi, 2006). However, other recent studies have shown that the role of credit rationing has been somewhat over-emphasized and that entrepreneurial saving plans may be able to overcome borrowing constraints (Cressy, 1996 and 2000; Parker, 2000 and 2002; Hurst and Lusardi, 2004). The risk of overstating the hindering role of credit constraints is particularly high in questionnaire analyses where nascent or newborn entrepreneurs are asked to list their main difficulties in starting a new firm; in fact, they have the self-indulgent tendency to indicate the lack of external financial support as the main cause of their problems, while in most cases this is just a symptom of more fundamental deficiencies internal to the firm.

Not surprisingly, it has also been demonstrated that education and human capital have an important role in increasing the likelihood of survival of new firms and in improving postentry economic performance (see Bates, 1990; Brüderl, Preisendörfer and Ziegler, 1992; Gimeno et al., 1997). In particular, specific rather than generic education and skills (Becker, 1964) are better predictors of improved post-entry performance, especially as far as NTBFs are concerned (see Almus and Nerlinger, 1999; Colombo and Grilli, 2005). In

${ }^{25}$ A recent contribution (Taymaz and Köksal, 2006) rightly points out that start-up size should be considered an endogenous variable in survival models. According to this view, entrepreneurs determine their entry size taking into account the risk of failure, limiting their pre-commitment where the risk is higher. If such is the case, the empirical result linking start-up size with a higher likelihood of survival should be considered - at least partially - spurious. 
this context, specificity refers to education in economic/managerial and technical/scientific fields and to previous work experience in technical and commercial functions within the same industry.

It is important to note that most potential entrepreneurs actually seem to favour the opposite strategy: they seem to be convinced that they need to be sufficiently good at a wide variety of things to ensure that the new business does not fail. As theorised by Lazear, (2004 and 2005), an individual who is well endowed in a variety of fields, a so-called "Jack-of-all trades", would have a high probability of becoming an entrepreneur, since entrepreneurs have to manage different people and tasks and so they have to be well-versed in a variety of abilities. As a consequence, this theory also predicts that nascent entrepreneurs should plan a human capital investment strategy which is well-balanced across different competences and expertises. Indeed - using cross section analyses - both Lazear (2005) and Wagner (2003) found that students who ended up as entrepreneurs had studied a much more varied curriculum than those who ended up working for others. On the whole, these researchers have then come to the conclusion that accumulation of a balanced skill-mix (that is general human capital) causally involves entrepreneurship and above-the-average post-entry performance (in contrast with the positive role of specific human capital discussed above).

However, recent papers cast severe doubts on the latter conclusion. First, individual unobservable characteristics may indeed simultaneously affect both skill accumulation and occupational choice, i.e. individuals innately well-versed in a variety of fields would have the incentive both to accumulate more balanced skills and to become entrepreneurs. If such is the case, no casual relationship would be detectable between the spread of knowledge across different fields and the choice to become an entrepreneur. Indeed, Silva (2006) using longitudinal data on Italian households - found that a "Jack-of-all trades" attitude had a sizeable effect on the probability of being an entrepreneur in a cross section framework, whilst no significant relationship was detectable in a proper fixed effects panel analysis. This result clashes with those from Lazear (2005) and Wagner (2003) and suggests that unobservables may be driving spurious cross-sectional results. Even more striking conclusions can be drawn on the basis of a work by Åstebro (2005). According to this author, if entrepreneurs tend to be generalist while employees tend to be specialist, this 
outcome might well be a consequence of a "taste for variety", i.e., both the choice of entrepreneurship and the preference for a general and broad education /experience may be driven by a taste for variety and not by an alleged optimization of the human capital investment (as in Lazear, 2004 and 2005). Indeed, Åstebro (2005) - using a sample of 5,008 Canadian inventors - finds convincing evidence that entrepreneurs have a more varied educational and professional background, but also that this variety has a negative effect on their income; individuals preferring variety would have a broader educational background, a more varied professional background, a greater likelihood of being an entrepreneur and ultimately a "below-the-average" post-entry performance. On the whole, an entrepreneur's widespread preference for general education and a high number of previous job experiences turns out to be a predictor of worse post-entry performance. In this regard, Åstebro’s (2005, p.29) conclusion is particularly neat: “...This result reminds us of the complete aphorism: "Jack of all trades - master of none”.

Other works have tried to single out whether the ex-ante personal characteristics of the founder may be seen as "predictors" of above-average post-entry performance. For example - and in accordance with the discussion put forward in the previous section - if the underlying motivation to start a new firm is explicitly linked to innovative projects, then better post-entry performance may be expected than if a new firm is started on the basis of a purely "defensive" motivation, such as the fear of becoming unemployed. For instance, Vivarelli and Audretsch $\left(1998^{26}\right)$ found that an innovative propensity was a good predictor of better post-entry performance in terms of economic returns, employment growth and export growth, while the opposite was true for the defensive "escape from unemployment" motivation (but this was only significant in relation to export intensity; ibidem, pp. 49495). By the same token, Arrighetti and Vivarelli $\left(1999^{27}\right)$, after applying a factor analysis on a sample of 147 spin-offs, found that innovative factors ${ }^{28}$ were significantly (99\% of confidence) correlated with post-entry performance. The cluster analysis applied to the

\footnotetext{
${ }^{26}$ For a description of the dataset used in this study, see footnote 13.

${ }^{27}$ Database described in previous footnote 13.

${ }^{28}$ Related both to the innovative motivations of the founder and to his/her previous innovative experience in the mother firm.
} 
same data consistently revealed that the innovative group was more likely to be destined to better post-entry performance, while defensive motivations such as the concern about future career developments and the fear of becoming unemployed were predictors of a below- average post-entry evolution (ibidem, p. 936).

In summary, as far as unemployment is concerned, there seem to be two stylized facts.

1) Those who have entered self employment from unemployment exit to a higher extent than those who have entered from paid employment (see Carrasco, 1999; Pfeiffer and Reize, 2000).

2) New founders who were formerly unemployed have on average lower economic outcomes and a lower propensity to positively contribute to job creation (see the discussion above; for a very recent paper, see Andersson and Wadensjö, 2006 ${ }^{29}$ )

In contrast, a propensity for innovation emerges as a positive predictor of post-entry performance. Consistently with the discussion above, Cefis and Marsili (2006a and 2006b) presented convincing evidence of an "innovation premium” in survival time: using Pavitt's (1984) taxonomy, they showed that young firms (less than four years old) in science-based and specialised supplier sectors were characterised by significantly higher chances of survival than firms in other sectors (ibidem, fig. 1 and table 2$)^{30}$. More in detail, Cefis and

${ }^{29}$ The authors use a large sample of Swedish-born men aged 20 to 60 years old and selfemployed in the period 1999-2002, who were either wage-earners, unemployed or inactive in 1998. After checking for fixed observable characteristics, such as age, education, marital status and place of residence, they show that those who were previously unemployed systematically have lower incomes compared to those who were previously wage earners. They also find that income from self-employment declines with the number of days spent in unemployment and that previously unemployed entrepreneurs are significantly more likely to be "solo" entrepreneurs, that is to have no employees.

${ }^{30}$ Evidence of a positive relationship between product and process innovation and survival can be found with regard to incumbent firms as well (see Calvo, 2006), especially as regards small firms (see Ortega-Argiles and Moreno, 2005). However, survival estimates may be affected by a sample selection bias: since firms which successfully commercialise innovations are also more likely to survive, studies may overstate the positive role of innovation (see Buddelmeyer, Jensen and Webster, 2006). A way to take the uncertain 
Marsili (2005) also showed that being an innovator enhanced the expected time of survival by 11 per cent compared with non-innovator counterparts ${ }^{31}$.

Similarly, deeply-rooted psychological motivation, such as the search for autonomy or the aspiration to a higher rank in one's social status, can obscure objective consideration of the actual economic chances of the new initiative and jeopardise either survival or business success. For example, if one looks at the typical motivation of so-called "social entrepreneurship" - that is the desire to be socially useful - it turns out that this is negatively and significantly correlated with post-entry profitability. In a previous study by one of the authors (Vivarelli, 2004 ${ }^{32}$ ) the "desire to be socially useful” was negatively and significantly (95\% confidence) correlated with a new firm's post-entry profitability, compared with the competitors in the same sector (ibidem, p.46).

Finally, from a managerial perspective, new founders who were previously employed as top managers in the same sector, who had better access to relevant information or had previous start-up experience (the so-called "sequential entrepreneurs") are expected to exhibit better post-entry business performance (for an empirical validation of these relationships, see Cooper, Gimeno-Gascon and Woo, 1994; Cressy, 1996; Arrighetti and Vivarelli, 1999; Bruderl and Preisendörfer, 2000; Lee and Tsang, 2001; Santarelli, 2006b;

nature of innovation and the failure risk associated with innovative start-ups into account might be to consider unsuccessful innovative new firms; however, these are very difficult to observe since questionnaire analyses on early failed firms are virtually impossible to design and supply.

31 In more general terms, one can propose the hypothesis that innovation and entrepreneurship are strictly complementary; the other side of the coin being that R\&D and innovation may have lower returns than expected just because of the lack of entrepreneurial skills (see Michelacci, 2003).

${ }^{32}$ The dataset used in this paper is described in previous footnote 13 . Since data on potential entrepreneurs are affected by sample selection (post-entry performance can be assessed only across a subset, the actual founders, of the examined population: founders and renouncers) the estimates were conducted through a two-stage Heckman procedure (for details about the adopted methodology, see Vivarelli, 2004, pp. 45 and ff.). 
Shane, 2001; Vivarelli, 2004). Some of these "predictors" may be effectively revealed through the filing of a well-articulated and stringent business-plan.

\section{$\underline{4 \text { Conclusions and policy implications }}$}

The discussion put forward so far makes it possible to derive some conclusive considerations and policy suggestions.

Firstly, notwithstanding an overall positive macroeconomic and regional impact (see Section 1), new firm formation is an extremely controversial phenomenon. Far from being solely the result of the entrepreneurial "creative destruction" process proposed by Schumpeterian advocates, any set of entrepreneurial ventures can be seen as a rather heterogeneous aggregate where innovative entrepreneurs are to be found together with passive followers, over-optimist gamblers and even escapees from unemployment.

Secondly, since founders are heterogeneous and may make "entry mistakes", most new firms are doomed to early failure; this type of entry is not conducive to technological renewal and economic growth, but simply to excess of entry, market churning and turbulence (this is well mirrored by the revealed statistically significant association between entry and exit at the firm, sectoral and macroeconomic levels).

Thirdly, determinants of entry vary from progressive factors such as demand and profit expectation, innovative potentialities, entrepreneurial human capital built through specific education, family environment and previous job experience, to misleading and regressive factors such as overconfidence, the desire to be independent, the preference for variety ("Jack-of-all-trades, master of none”), the fear of unemployment. Ironically, some vulnerable groups characterised by regressive determinants and thus by the highest expected failure rates, are nonetheless the most commonly targeted by start-up promotion policies (a good example being the widespread incentives for the unemployed to start a new business).

Fourthly, ex-ante "genetic" features of the founder may be predictors of survival chances and post-entry business performance. For instance, a larger size, the absence of credit 
constraints, and a larger informational set allowing “active learning”, can be considered as positive predictors of a higher likelihood of survival, while a previous status of unemployment or the absence of an adequate incubator background can be seen as predictors of early failure. By the same token, a higher endowment of specific education and human capital, the importance of innovative motivation and previous experience in managerial and entrepreneurial roles have been shown to be correlated with an above-theaverage post-entry business performance.

In this framework, industrial policy is characterized by an important trade-off .On the one hand, one would be tempted to allow market selection to do its own job fully. Since new firm formation is affected by entry mistakes and churning, market selection can efficiently single out real entrepreneurs from "revolving door" founders and so pick up those newborn firms which can really contribute to technological upgrading and economic growth and are likely to displace the least efficient ones among incumbent firms (the 'forest' metaphor). In this view, (early) failure should be seen as socially optimal rather than the result of either financial market imperfections or other market failures. As a matter of fact, an entry subsidy may (temporarily) cancel - or at least reduce - the intrinsic differentials between ex-ante less efficient and more efficient newborn firms, therefore distorting both market selection and the learning process that new founders have to undertake. Once the subsidy expires, the "bad entrepreneur" suddenly realises his/her inefficiency and leaves the market, cancelling the temporary effect of the subsidy in terms of new firm formation and job creation ${ }^{33}$.

33 The early stages of a firm's life cycle are indeed characterised by important adjustment, learning and increasing return effects which may imply either early failure or convergence to the MES. In previous papers, we showed that in the very first years after start-up, efficient firms which entered the market at a suboptimal scale survive through accelerated growth (in contrast with Gibrat's law, smaller new firms grow faster than their larger counterparts), while only in subsequent years newborn firms assume a Gibrat-like behaviour (Lotti, Santarelli and Vivarelli, 2001 and 2003; Santarelli and Vivarelli, 2002; for the role of dynamic increasing returns and cumulative corporate competences in shaping the growth process of firms, see Bottazzi and Secchi, 2006a and 2006b). These outcomes support an additional argument against incentives to entry: in fact, a subsidy may 
More specifically, an entry subsidy represents either a "deadweight" or a "substitution" effect. The first occurs when the beneficiary from the subsidy is a newborn entrepreneurial firm which would have survived and grown in any case; the second when the incentive supports a revolving door firm which would have exited the market in absence of the subsidy. In the latter case, the distortion is larger, since the subsidy is not only a social waste but also implies the substitution of a potentially more efficient entrant by a subsidized inefficient firm. In fact, in the presence of a subsidy, the newborn firm adjusts its own capacity not on the basis of either passive or active learning, but as a consequence of the artificial support brought about by the received subsidy. Once the subsidy expires, the "bad entrepreneur" becomes aware of his/her inefficiency and leaves the market. If such is the case, the subsidy induces a substitution effect against more efficient potential entrants and delays the exit of less efficient newborn firms.

On the other hand, economic policy might provide "guidelines" to make market selection more efficient. For example, new firm formation might be stimulated in those sectors and regions where the technological and incubator conditions are more likely to generate real entrepreneurial activities rather than revolving door firms (see Section 2). Likewise, premarket selection might be carried out through interviews, examination of business plans and provision of incentives intended to select those potential founders ("nascent entrepreneurs") characterized by a dominance of "good predictors” instead of regressive individual features and motivations (see Section 3). However, while this strategy minimizes the risk of possible substitution effects, it maximises the occurrence of widespread deadweight effects.

In contrast with this cautious and extremely selective approach, most local, national and international authorities seem to have favoured "erga omnes" policies, characterised by general and often automatic entry subsidies. This is very unfortunate, since the discussion put forward in this paper implies that incentives should be: 1) highly selective; 2) favouring nascent entrepreneurs endowed with progressive motivations and promising predictors of better business performance; and 3) leading to the lowest possible distortion of the post-entry market selection of the most efficient entrepreneurs. Indeed, entry and the

confuse the newborn entrepreneur's perception of both his/her cumulative potentialities and market signals and interfere with his/her optimal growth pattern. 
first years of a firm's life cycle are neither a smooth process nor a random walk, but are characterised by important selection and learning processes that should be allowed to run their course.

In this framework, subsidies should be conditional on an obvious and unambiguous occurrence of a market failure (such as capital market imperfections) which prevents otherwise efficient firms from becoming established and growing. Hence, entry subsidies should be allowed only in exceptional situations, while in "normal times" policy makers should refrain from artificially supporting new firm formation

To conclude in a provocative way, while most politicians and practitioners are claiming that the economy needs more new firms and entrepreneurship, one may well argue that the opposite is the case. For the reasons discussed above, ranging from regressive determinants to over-optimism, we might conclude that modern developed economies are affected by too many start-ups and that policy makers should be worrying about "excess of entry", turbulence and revolving door market churning, rather than an alleged lack of “entrepreneurship”. 


\section{References}

Acs, Z.J. (2006), New Firm Formation and the Region: Empirical Results from the United States, in E. Santarelli (ed.), Entrepreneurship, Growth and Innovation: The Dynamics of Firms and Industries, New York, Springer, 106-133.

Acs, Z.J. and Audretsch, D.B. (1989a), Small-firm Entry in US Manufacturing, Economica, 56, 255-65.

Acs, Z.J. and Audretsch, D.B. (1989b), Births and Firm Size, Southern Economic Journal 56, 46775.

Acs, Z.J. and Audretsch D.B. (1990), Innovation and Small Firms, Cambridge (Mass), MIT Press.

Acs, Z.J., Audretsch D.B., Braunerhjelm, P. and Carlsson B. (2005), Growth and Entrepreneurship: An Empirical Assessment, Discussion Papers on Entrepreneurship, Growth and Public Policy, n. 3205, Jena, Max Planck Institute of Economics.

Agarval, R. and Audretsch, D.B. (2001), Does Entry Size Matter? The Impact of the Life Cycle and Technology on Firm Survival, Journal of Industrial Economics, 49, 21-43.

Aghion, P. and Howitt, P. (1992), A Model of Growth Through Creative Destruction, Econometrica, 60, 323-51.

Almus, M. and Nerlinger, E.A. (1999), Growth of New Technology-Based Firms: Which Factors Matter?, Small Business Economics, 13, 141-54.

Andersson, P. and Wadensjö, E. (2006), Do the Unemployed Become Successful Entrepreneurs? A Comparison between the Unemployed, Inactive and Wage-Earners, IZA discussion paper no. 2402, October, Bonn, IZA.

Arauzo-Carod, J.M. and Segarra-Blasco, A. (2005), The Determinants of Entry are not Independent of Start-up Size: Some Evidence from Spanish Manufacturing, Review of Industrial Organization, 27, $147-65$.

Armington, C. and Acs, Z.J. (2002), The Determinants of Regional Variation in New Firm Formation, Regional Studies, 36, 33-45.

Arrighetti, A. and Vivarelli, M. (1999), The Role of Innovation in the Postentry Performance of New Small Firms: Evidence from Italy, Southern Economic Journal, 65, 927-39.

Åstebro, T. (2003), The Return to Independent Invention: Evidence of Risk-seeking, Extreme Optimism or Skewness Loving?, Economic Journal, 113, 226-39.

Åstebro, T. (2005), Does it Pay To Be a Jack-of-all-trades?, Rotman School of Management, University of Toronto, mimeo, Toronto.

Audretsch, D.B. (1991), New-Firm Survival and the Technological Regime, Review of Economics and Statistics, 73, 441-50.

Audretsch, D.B. (1995), Innovation and Industry Evolution, Cambridge (Mass), MIT Press.

Audretsch, D.B. and Feldman, M.P. (1996), R\&D Spillovers and the Geography of Innovation and Production, American Economic Review, 86, 630-40.

Audretsch, D.B. and Feldman, M.P. (2004), Knowledge Spillovers and the Geography of Innovation, in Henderson, J.V. and Thisse, J.F. (eds.), Handbook of Regional and Urban Economics, Vol. 4, Amsterdam, Elsevier, 2713-39. 
Audretsch, D.B. and Keilbach, M.C. (2004a), Entrepreneurship and Regional Growth: an Evolutionary Interpretation, Journal of Evolutionary Economics, 14, 605-16.

Audretsch, D.B. and Keilbach, M.C. (2004b), Entrepreneurship Capital and Economic Performance, Regional Studies, 38, 949-59.

Audretsch, D.B., Keilbach, M.C. and Lehmann, E.E. (2006), Entrepreneurship and Economic Growth, Oxford, Oxford University Press.

Audretsch, D.B. and Mahmood, T. (1995), New Firm Survival: New Results Using a Hazard Function, Review of Economics and Statistics, 77, 97-103.

Audretsch, D.B., Santarelli, E. and Vivarelli, M. (1999a), Start Up Size and Industrial Dynamics: Some Evidence from Italian Manufacturing, International Journal of Industrial Organization, 17, 965-83.

Audretsch, D.B., Santarelli, E. and Vivarelli, M. (1999b), Does Start Up Size Influence the Likelihood of Survival?, in Audretsch, D. and Thurik, R. (eds.) , Innovation, Industry Evolution and Employment, Cambridge, Cambridge University Press, 280-96.

Audretsch, D.B. and Thurik, A.R. (2000), Capitalism and Democracy in the $21^{\text {st }}$ Century: From the Managed to the Entrepreneurial Economy, Journal of Evolutionary Economics, 10, 17-34.

Audretsch, D.B. and Thurik, A.R. (2004), A Model of the Entrepreneurial Economy, International Journal of Entrepreneurship Education, 2, 143-66.

Audretsch, D.B. and Vivarelli, M. (1995), New Firm Formation in Italy, Economics Letters, 48, 7781.

Audretsch, D.B. and Vivarelli, M. (1996a), Determinants of New-Firm Startups in Italy, Empirica 23, 91-105.

Audretsch, D.B. and Vivarelli, M. (1996b), Firm Size and R\&D Spillovers: Evidence from Italy, Small Business Economics, 8, 249-58.

Baldwin, J.R. and Gorecki, P.K. (1987), Plant Creation Versus Plant Acquisition: The Entry Process in Canadian Manufacturing, International Journal of Industrial Organization, 5, 27-41.

Baldwin, J.R. and Gorecki, P.K. (1991), Firm Entry and Exit in the Canadian Manufacturing Sector, Canadian Journal of Economics, 24, 300-23.

Baldwin, J.R., and Rafiquzzaman, M. (1995), Selection Versus Evolutionary Adaptation Learning and Post-entry Performance, International Journal of Industrial Organization, 13, 501-22.

Baptista, R. and Karaöz, M. (2006), Turbulence in Entry and Exit over the Product Life Cycle, paper presented at the $3^{\text {rd }}$ HE.W.P.E.M. (Hellenic Workshop on Efficiency and Productivity Measurement): "Industry Dynamics, Productivity, Entrepreneurship and Growth", University of Patras, June 16-18.

Baptista, R., Van Stel, A.J. and Thurik, A.R. (2006), Entrepreneurship, Industrial Restructuring and Unemployment in Portugal, in E. Santarelli (ed.), Entrepreneurship, Growth, and Innovation: The Dynamics of Firms and Industries, New York, Springer, 223-241.

Bartelsman, E., Scarpetta, S. and Schivardi, F. (2005), Comparative Analysis of Firm Demographics and Survival: Evidence from Micro-level Sources in OECD Countries, Industrial and Corporate Change, 14, 365-91.

Bates, T. (1990), Entrepreneur Human Capital Inputs and Small Business Longevity, Review of Economics and Statistics, 72, 551-59. 
Baumol, W.J. (2005), Entrepreneurship and Invention: Toward Their Microeconomic Value Theory, AEI-Brookings Joint Center for Regulatory Studies, related publication n. 05-38, Washington, Joint Center.

Becchetti, L. and Trovato, G. (2002), The Determinants of Growth for Small and Medium Sized Firms. The Role of Availability of External Finance, Small Business Economics, 19, 291-306.

Becker, G.S. (1964), Human Capital: A Theoretical and Empirical Analysis, New York, Columbia University Press.

Beesley, M.E and Hamilton, R.T. (1984), Small Firms' Seedbed Role and the Concept of Turbulence, Journal of Industrial Economics, 33, 217-31.

Binks, M. and Ennew, C. (1996), Growing Firms and the Credit Constraint, Small Business Economics, 8, 17-25.

Blanchflower, D., and Meyer, B. (1994), A Longitudinal Analysis of Young Entrepreneurs in Australia and the United States, Small Business Economics, 6, 1-20.

Blanchflower, D. and Oswald, A. (1998), What Makes an Entrepreneur?, Journal of Labor Economics, 16, 26-60.

Boeri, T. and Cramer, U. (1992), Employment Growth, Incumbents and Entrants: Evidence from Germany, International Journal of Industrial Organization, 10, 545-66.

Bottazzi, G. and Secchi, A. (2006a), Gibrat's Law and Diversification, Industrial and Corporate Change, 15, 847-75.

Bottazzi, G. and Secchi, A. (2006b), Explaining the Distribution of Firms Growth Rates, Rand Journal of Economics, 37, 234-63.

Breschi, S., Malerba, F. and Orsenigo, L. (2000), Technological Regimes and Schumpeterian Patterns of Innovation, Economic Journal, 110, 388-410.

Brüderl, J. and Preisendörfer, P. (2000), Fast Growing Businesses: Empirical Evidence from a German Study, International Journal of Sociology, 30, 45-70.

Brüderl, J., Preisendörfer, P. and Ziegler, R. (1992), Survival Chances of Newly Founded Business Organizations, American Sociological Review, 72, 227-42.

Buddelmeyer, H., Jensen, P.H. and Webster, E. (2006), Innovation and the Determinants of Firm Survival, IZA discussion paper no. 2386, October, Bonn, IZA.

Burke, A., FitzRoy, F. and Nolan, M.A. (2006), What Makes a Die-Hard Entrepreneur? Beyond the 'Employee or Entrepreneur' Dichotomy, IZA discussion paper no. 2307, September, Bonn, IZA.

Cabral, L. (1995), Sunk Costs, Firm Size and Firm Growth, Journal of Industrial Economics, 43, 161-72.

Cabral, L. (1997), Entry Mistakes, Centre for Economic Policy Research, Discussion Paper No. 1729, London, CEPR:

Cabral, L. and Mata, J. (2003), On the Evolution of the Firm Size Distribution: Facts and Theory, American Economic Review, 93, 1075-90.

Calvo, J.L. (2006), Testing Gibrat's Law for Small, Young and Innovating Firms, Small Business Economics, 26, 117-23.

Camerer, C. and Lovallo, D. (1999), Overconfidence and Excess Entry: An Experimental Approach, American Economic Review, 89, 306-18. 
Carpenter, R.E. and Petersen, B.C. (2002), Is the Growth of Small Firms Constrained by Internal Finance?, Review of Economics and Statistics, 84, 298-309.

Carrasco, R. (1999), Transitions to and from Self-employment in Spain, Oxford Bulletin of Economics and Statistics, 61, 315-41

Carree, M. and Thurik, A.R., (2006), Understanding the Role of Entrepreneurship for Economic Growth, in Carree, M. and Thurik, A.R. (Eds.), The Handbook of Entrepreneurship and Economic Growth, Cheltenham, Elgar, forthcoming.

Cathcart, D.G. and Johnson, P.S. (1979), New Manufacturing firms and Regional Development: some Evidence from the Northern Regions, Regional Studies, 13, 269-80.

Caves, R.E. (1998), Industrial Organization and New Findings on the Turnover and Mobility of Firms, Journal of Economic Literature, 36, 1947-82.

Cefis, E. and Marsili, O. (2005), A Matter of Life and Death: Innovation and Firm Survival, Industrial and Corporate Change, 14, 1167-92.

Cefis, E. and Marsili, O. (2006a), Innovation Premium and the Survival of Entrepreneurial Firms in the Netherlands, in E. Santarelli (ed.), Entrepreneurship, Growth, and Innovation: The Dynamics of Firms and Industries, New York, Springer, 183-198.

Cefis, E. and Marsili, O. (2006b), Survivor: The Role of Innovation in Firm’s Survival, Research Policy, 35, 626-41.

Chiaromonte, F. and Dosi, G. (1993), Heterogeneity, Competition, and Macroeconomic Dynamics, Structural Change and Economic Dynamics, 4, 39-63.

Coelho, M.P., de Meza, D. and Reyniers, D. (2004), Irrational Exuberance, Entrepreneurial Finance and Public Policy, International Tax and Public Finance, 11, 391-417.

Colombo, M.G., Delmastro M. and Grilli, L. (2004), Entrepreneurs' Human Capital and the Startup Size of New Technology-based Firms, International Journal of Industrial Organization, 22, 1183-1211.

Colombo, M.G. and Grilli, L. (2005), Founders' Human Capital and the Growth of New Technology-Based Firms: A Competence-Based View, Research Policy, 34, 795-816.

Cooper, A.C. (1985), The Role of Incubator Organizations in the Founding of Growth-oriented Firms, Journal of Business Venturing, 1, 75-86.

Cooper, A.C., Gimeno-Gascon, F.J. and Woo, C.Y. (1994), Initial Human Capital and Financial Capital as Predictors of New Venture Performance, Journal of Business Venturing, 9, 371-96.

Cooper, A.C., Woo, C.Y. and Dunkelberg, W.C. (1989), Entrepreneurship and the Initial Size of Firms, Journal of Business Venturing, 4, 317-32.

Creedy, J. and Johnson, P.S. (1983), Firm Formation in Manufacturing Industry, Applied Economics, 15, 177-85.

Cressy, R. (1996), Are Business Start-ups Debt-rationed?, Economic Journal, 106, 1253-70.

Cressy, R. (2000), Credit Rationing or Entrepreneurial Risk Aversion? An Alternative Explanations for the Evans and Jovanovic Finding, Economics Letters, 66, 235-40.

Cressy, R. (2006), Why Do Most Firms Die Young?, Small Business Economics, 26, 103-16.

De Meza, D. (2002), Overlending?, Economic Journal, 112, F17-F31.

De Wit, G., and Van Winden, F.A.A.M. (1989), An Empirical Analysis of Self-Employment in the Netherlands, Small Business Economics, 1, 263-72. 
Dosi, G. (1988), Sources, procedures and microeconomic effects of innovation, Journal of Economic Literature, 26, 1120-71.

Dosi, G. and Egidi, M. (1991), Substantive and Procedural Uncertainty. An Exploration of Economic Behaviors in Complex and Changing Environment, Journal of Evolutionary Economics, $1,145-68$.

Dosi, G. and Lovallo, D. (1998), Rational Entrepreneurs or Optimistic Martyrs? Some Considerations on Technological Regimes, Corporate Entries, and the Evolutionary Role of Decision Biases, in Garud, R., Nayyar, P. and Shapiro, Z. (eds.), Foresights and Oversights in Technological Change, Cambridge, Cambridge University Press, 41-68.

Dosi, G., Marsili, O., Orsenigo, L. and Salvatore, R. (1995), Learning, Market Selection and the Evolution of Industrial Structures, Small Business Economics, 7, 411-36.

Dunne, P. and Hughes, A. (1994), Age, Size, Growth and Survival: UK Companies in the 1980s, Journal of Industrial Economics, 42, 115-40.

Dunne, T., Roberts, M.J. and Samuelson, L. (1988), Patterns of Firm Entry and Exit in U.S. Manufacturing Industries, Rand Journal of Economics, 19, 495-515.

Dunne, T., Roberts, M.J. and Samuelson, L. (1989), The Growth and Failure of US Manufacturing Plants, Quarterly Journal of Economics, 104, 671-98.

Endres, A.M. and Woods, C.R. (2006), Modern Theories of Entrepreneurial Behavior: A Comparison and Appraisal, Small Business Economics, 26, 189-202.

Ericson, R. and Pakes, A. (1995), Markov-Perfect Industry Dynamics: a Framework for Empirical Work, Review of Economic Studies, 62, 53-82.

Evans, D.S. (1987), The Relationship Between Firm Growth, Size, and Age: Estimates for 100 Manufacturing Industries, Journal of Industrial Economics, 35, 567-81.

Evans, D.S. and Jovanovic, B. (1989), An Estimated Model of Entrepreneurial Choice under Liquidity Constraints, Journal of Political Economy, 97, .808-27.

Evans, D.S. and Leighton L.S. (1989), Some Empirical Aspects of Entrepreneurship, American Economic Review, 79, 519-35.

Evans, L.B. and Leighton L.S. (1990), Small Business Formation by Unemployed and Employed Workers, Small Business Economics, 2, 319-30.

Fagiolo, G. and Luzzi, A. (2006), Do Liquidity Constraints Matter in Explaining Firm Size and Growth? Some Evidence from the Italian Manufacturing Industry, Industrial and Corporate Change, 15, 1-39.

Fazzari, S.M., Hubbard, R.G. and Petersen, B.C. (1988), Financing Constraints and Corporate Investment, Brookings Papers on Economic Activity, 115, 695-713.

Foti, A. and Vivarelli, M. (1994), An Econometric Test of the Self-employment Model: The case of Italy, Small Business Economics, 6, 81-93.

Fujita, M. and Thisse, J.F. (2002), Economics of Agglomeration: Cities, Industrial Location, and Regional Growth, Cambridge, Cambridge University Press.

Garofoli, G. (1994), New Firm Formation and Regional Development: the Italian Case, Regional Studies, 28, 381-93.

Gelderen van, M., Thurik, R. and Bosma, N. (2006), Success and Risk Factors in the Pre-Startup Phase, Small Business Economics, 26, 319-35. 
Geroski, P.A. (1995), What do We know about Entry?, International Journal of Industrial Organization, 13, 421-40.

Geroski, P.A. and Mazzucato, M. (2001), Modelling the Dynamics of Industry Populations, International Journal of Industrial Organization, 19, 1003-22.

Geroski, P.A. and Schwalbach J. (eds.), (1991), Entry and Market Contestability: An International Comparison, Oxford, Basil Blackwell.

Gibrat, R. (1931), Les Inegalites Economiques, Paris, Librairie du Recueil Sirey.

Gimeno, J, Folta, T., Cooper, A. and Woo, C. (1997), Survival of the Fittest? Entrepreneurial Human Capital and the Persistence of Underperforming Firms, Administrative Science Quarterly, 42, 750-83.

Globerman, S., Shapiro, D. and Vining, A. (2005), Clusters and Intercluster Spillovers: Their Influence on the Growth and Survival of Canadian Information Technology Firms, Industrial and Corporate Change,14, 27-60.

Grilo, I. and Thurik, A.R. (2006), Entrepreneurship in the Old and New Europe, in E. Santarelli (ed.), Entrepreneurship, Growth, and Innovation: The Dynamics of Firms and Industries, New York, Springer, 75-103.

Grossman, G. and Helpman, E. (1991), Innovation and Growth in the World Economy, Cambridge (Mass.), MIT Press.

Guiso, L. and Schivardi, F. (2005), Learning To Be an Entrepreneur, CEPR Discussion Paper $n$. 5290, London, Centre for Economic Policy Research.

Hall, B. (1987), The Relationship Between Firm Size and Firm Growth in the US Manufacturing Sector, Journal of Industrial Economics, 35, 583-606.

Hamilton, R.T (1989), Unemployment and Business Formation Rates: Reconciling Time-series and Cross-section Evidence, Environment and Planning, 21, 249-55.

Hart, P.E. and Oulton, N. (1996), Growth and Size of Firms, Economic Journal, 106, 1242-52.

Hart, P.E. and Oulton, N. (2001), Galtonian Regression, Company Age and Job Generation 198695, Scottish Journal of Political Economy, 48, 82-98.

Hébert, R.F. and Link, A.N. (1989), In Search of the Meaning of Entrepreneurship, Small Business Economics, 1, 39-49.

Heiner, R.A. (1983), The Origin of Predictable Behavior, American Economic Review, 73, 560-95.

Helfat, C.E. and Lieberman, M.B. (2002), The Birth of Capabilities: Market Entry and the Importance of Pre History, Industrial and Corporate Change, 11, 725-60.

Henrekson, M. (2005), Entrepreneurship: A Weak Link in the Welfare State?, Industrial and Corporate Change, 14, 437-67.

Highfield, R. and Smiley, R. (1987), New Business Starts and Economic Activity: An Empirical Investigation, International Journal of Industrial Organization, 5, 51-66.

Holtz-Eakin, D., Joulfaian, D., Rosen, H. (1994), Sticking it out: Entrepreneurial Survival and Liquidity Constraints, Journal of Political Economy, 102, 53-75.

Hopenhayn, H. (1992), Entry, Exit and Firm Dynamics in Long Run Equilibrium, Econometrica $60,1127-1150$.

Hout, M. and Rosen, H. (2000), Self-employment, Family Background and Race, Journal of Human Resources, 35, 670-692. 
Hurst, E. and Lusardi, A. (2004), Liquidity Constraints, Household Wealth and Entrepreneurship, Journal of Political Economy, 112, 319-347.

Kan, K. and Tsai, W.D. (2006), Entrepreneurship and Risk Aversion, Small Business Economics, 26, 465-74.

Khemani, R.S. and Shapiro, D.M. (1986), The Determinants of New Plant Entry in Canada, Applied Economics, 18, 1243-57.

Kihlstrom, R.E and Laffont, J.J. (1979), A General Equilibrium Entrepreneurial Theory of Firm Formation Based on Risk Aversion, Journal of Political Economy, 87, 719-48.

Kirzner, I. (1973), Competition and Entrepreneurship, Chicago, University of Chicago Press.

Kirzner, I. (1997), Entrepreneurial Discovery and the Competitive Market Process: An Austrian Approach, Journal of Economic Literature, 35, 60-85.

Klepper, S. (2001), Employee Startups in High-tech Industries, Industrial and Corporate Change, $10,639-674$.

Knight, F.H. (1921), Uncertainty and Profit, New York, Houghton Mifflin.

Krugman, P. (1991), Increasing Returns and Economic Geography, Journal of Political Economy, 99, 483-499.

Johnson, P.S. (1983), New Manufacturing Firms in the U.K. Regions, Scottish Journal of Political Economy, 30, 75-79.

Johnson, P.S. (1986), New Firms: An Economic Perspective, London, Allen \& Unwin.

Johnson, P.S. (2005), Targeting Firm Births and Economic Regeneration in a Lagging Region, Small Business Economics, 24, 451-64.

Johnson, P.S., Parker, S.C. and Wijbenga, F. (2006), Nascent Entrepreneurship Research: Achievements and Opportunities, Small Business Economics, 27, 1-4.

Jovanovic, B. (1982), Selection and Evolution of Industry, Econometrica, 50, 649-670.

NBER working paper n. 9109, Cambridge (Mass.), National Bureau of Economic Research.

Lazear, E. (2004), Balanced Skills and Entrepreneurship”, American Economic Review Papers and Proceedings, 94, 208-11.

Lazear, E. (2005), Entrepreneurship, Journal of Labor Economics, 23, 649-680

Lee, D. and Tsang, E. (2001), The Effects of Entrepreneurial Personality, Background and Network Activity on Venture Growth, Journal of Management Studies, 38, 583-602.

Lee, S.Y, Florida, R. and Acs, Z.J. (2004), Creativity and Entrepreneurship: A Regional Analysis of New Firm Formation, Regional Studies, 38, 879-91.

Levenson, A.R. and K.L. Willard (2000), Do Firms Get the Financing They Want? Measuring Credit Rationing Experienced by Small Businesses in the US, Small Business Economics, 14, 8394.

Lindh, T. and Ohlsson, D.N. (1996), Self-employment and Windfall Gains: Evidence from the Swedish Lottery, Economic Journal, 106, 1515-1526.

Lotti, F. and Santarelli, E. (2004), Industry Dynamics and the Distribution of Firm Sizes: A Nonparametric Approach, Southern Economic Journal, 70, 443-466.

Lotti, F., Santarelli, E. and Vivarelli, M. (2001), The Relationship Between Size and Growth: The Case of Italian Newborn Firms, Applied Economics Letters, 2001, 8, 451-454. 
Lotti, F., Santarelli, E. and Vivarelli, M. (2003), Does Gibrat's Law Hold Among Young, Small Firms?, Journal of Evolutionary Economics, 13, 213-235.

Lucas, R.E., Jr. (1978), On the Size Distribution of Business Firms, Bell Journal of Economics, 9, 508-523.

Lucas, R.E., Jr. (1988), On the Mechanics of Economic Development, Journal of Monetary Economics, 22, 3-42.

Manjón-Antolín, M.C. (2004), Firm Size and Short-term Dynamics in Aggregate Entry and Exit, CentER Discussion Paper, 2, Tilburg University, Center for Economic Research.

Mansfield, E. (1962), Entry, Gibrat's Law, Innovation and the Growth of Firms, American Economic Review, 52, 1023-51.

Marshall, A. (1961), Principles of Economics, Cambridge, Macmillan (first edition 1890).

Marsili, O. (2002), Technological Regimes and Sources of Entrepreneurship, Small Business Economics, 19, 217-31.

Masuda, T. (2006), The Determinants of Latent Entrepreneurship in Japan, Small Business Economics, 26, 227-40.

Mata, J., Portugal, P.and Guimaraes, P. (1995), The Survival of New Plants: Start-up Conditions and Post-entry Evolution, International Journal of Industrial Organization, 13, 459-482.

Michelacci, C. (2003), Low Returns in R\&D Due to the Lack of Entrepreneurial Skills, Economic Journal, 113, 207-25.

Michelacci, C. and Silva, O. (2005), Why so Many Local Entrepreneurs?, CEMFI Working Paper n. 0506, Madrid, CEMFI.

Minniti, M. and Venturelli, P. (2000), Global Entrepreneurship Monitor. National Entrepreneurship Assessment: Italy, 2000 Executive Report, Babson Park (Mass.), Babson College.

Norton, W.I. Jr. and Moore, W.T. (2006), The Influence of Entrepreneurial Risk Assessment on Venture Launch or Growth Decisions, Small Business Economics, 26, 215-26.

OECD (2003), The Sources of Economic Growth in OECD Countries, Paris, OECD.

Olmo, S. (2006), The Jack-of-All-Trades Entrepreneur: Innate Talent or Acquired Skill?, IZA discussion paper no. 2264, August, Bonn, IZA.

Orr, D. (1974), The Determinants of Entry: A Study of the Canadian Manufacturing Industries, Review of Economics and Statistics, 56, 58-66.

Ortega-Argiles, R. and Moreno, R. (2005), Firm Competitive Strategies and the Likelihood of Survival. The Spanish Case, paper presented at the 45th Congress of the European Regional Science Association, Vrije Universiteit, Amsterdam, August, 23-27.

Oxenfeldt, A.R. (1943), New Firms and Free Enterprise: Pre-War and Post-War Aspects, Washington, American Council on Public Affairs.

Pakes, A. and Ericson, R. (1998), Empirical Implications of Alternative Models of Firm Dynamics, Journal of Economic Theory, 79, 1-45.

Palich, L.E. and Bagby, D.R. (1995), Using Cognitive Theory to Explain Entrepreneurial Risk Taking: Challenging Conventional Wisdom, Journal of Business Venturing, 10, 425-38.

Parker, S.C. (1996), A Time-series Model of Self-employment under Uncertainty, Economica, 63, 459-475. 
Parker, S.C. (1997), The Effects of Risk on Self-employment, Small Business Economics, 9, 515522.

Parker, S.C. (2000), Saving to Overcome Borrowing Constraints: Implications for Small Business Entry and Exit, Small Business Economics, 15, 223-32.

Parker, S.C. (2002), Do Banks Ration Credit to New Enterprises? And should Government Intervene? Scottish Journal of Political Economy, 49, 162-95.

Parker, S.C. (2004), The Economics of Self-Employment and Entrepreneurship, Cambridge, Cambridge University Press.

Parker, S.C. (2006), New Agendas in the Economics of Entrepreneurship: Optimism, Education, Wealth and Entrepreneurship, paper presented at the $3^{\text {rd }}$ HE.W.P.E.M. (Hellenic Workshop on Efficiency and Productivity Measurement): "Industry Dynamics, Productivity, Entrepreneurship and Growth”, University of Patras, June 16-18.

Parker, S.C. and van Praag, M. (2006). "Schooling, Capital Constraints and Entrepreneurial Performance: The Endogenous Triangle", forthcoming in Journal of Business and Economic Statistics.

Pavitt K. (1984), Sectoral Patterns of Technical Change: Towards a Taxonomy and a Theory, Research Policy, 13, 343-73.

Pfeiffer, F. and Reize, F. (2000), Business Start-ups by the Unemployed - An Econometric Analysis Based on Firm Data, Labour Economics, 7, 629-63.

Piergiovanni, R. and Santarelli, E. (1995), The Determinants of Firm Start-up and Entry in Italian Producer Services, Small Business Economics, 7, 221-230.

Piergiovanni, R., Klomp, L., Santarelli, E. and Thurik, A.R. (2003), ),Gibrat's Law and the Firm Size/Firm Growth Relationship in Italian Small Scale Services, Revue d'Economie Industrielle, 2003, No. 102, pp. 69-82;

Reid, G.C. (1991), Staying in Business, International Journal of Industrial Organization, 9, 54556.

Reynolds, P.D. (1997), Who Starts New Firms? - Preliminary Explorations of Firms-in-Gestation, Small Business Economics, 9, 449-62.

Reynolds, P.D., Camp, M. S., Bygrave, W.D., Autio, E. and Hay, M. (2001), Global Entrepreneurship Monitor. 2001 Summary Report, London, London Business School and Babson College.

Romer, P.M. (1986), Increasing Returns and Long-Run Growth, Journal of Political Economy, 98, S71-S102.

Romer, P.M. (1990), Endogenous Technical Change, Journal of Political Economy, 94, 1002-37.

Santarelli, E. (2000), The Duration of New Firms in Banking: An Application of Cox Regression Analysis, Empirical Economics, 25, 315-325.

Santarelli, E. (2006a), Introduction, in E. Santarelli (ed.), Entrepreneurship, Growth, and Innovation: The Dynamics of Firms and Industries, New York, Springer, xiii-xx.

Santarelli, E. (2006b), Entrepreneurship, Innovation, and the Evolution of Industrial Districts, in E. Santarelli (ed.), Entrepreneurship, Growth, and Innovation: The Dynamics of Firms and Industries, New York, Springer, 165-182. 
Santarelli, E., Carree, M. and Verheul, I. (2006), Unemployment and Firm Entry and Exit: An Update on a Controversial Relationship, paper presented at the $3^{\text {rd }}$ HE.W.P.E.M. (Hellenic Workshop on Efficiency and Productivity Measurement): "Industry Dynamics, Productivity, Entrepreneurship and Growth”, University of Patras, June 16-18.

Santarelli, E. and Pesciarelli, E. (1990), The Emergence of a Vision: The Development of Schumpeter's Theory of Entrepreneurship, History of Political Economy, 22, 677-696.

Santarelli, E. and Vivarelli, M. (2002), Is Subsidizing Entry an Optimal Policy?, Industrial and Corporate Change, 11, 39-52.

Schumpeter, J.A. (1908), Das Wesen und Der Hauptinhalt der Theoretischen Nationalökonomie, Leipzig, Duncker and Humblot.

Schumpeter, J.A. (1934), The Theory of Economic Development, Cambridge (Mass.), Harvard University Press (first edition in German:1912).

Schumpeter, J.A. (1943), Capitalism, Socialism and Democracy, New York, Harper.

Shane, S. (2000), Prior Knowledge and the Discovery of Entrepreneurial Opportunities, Organization Science, 11, 448-69.

Shane, S. (2001), Technological Opportunities and New Firm Creation, Management Science, 47, 205-20.

Shane, S. (2003), A general Theory of Entrepreneurship. The Individual-Opportunity Nexus, Cheltenham, Elgar.

Silva, O. (2006), The Jack-of-All-Trades Entrepreneur: Innate Talent or Acquired Skill?, IZA discussion paper no. 2264, August, Bonn, IZA.

Simon, H. (1982), Models of Bounded Rationality, Cambridge (Mass.), MIT Press.

Simon, H. (1987), Bounded Rationality, in Eatwell, J. et al. (Eds), The New Palgrave: A Dictionary of Economics, London, Macmillan, Vol. 1, 266-68.

Small Business Service (2001), Global Entrepreneurship Monitor. 2001 UK Executive Report, London, London Business School.

Stevenson, H.H. and Gumpert, D.E. (1985), The Heart of Entrepreneurship, Harvard Business Review, March, 9-24

Storey, D.J. (1982), Entrepreneurship and the New Firm, London, Croom Helm.

Storey, D.J. (1991), The Birth of New Firms - Does Unemployment Matter? A Review of the Evidence, Small Business Economics, 3, 167-78.

Storey, D.(1994), Understanding the Small Business Sector, London, Routledge.

Storey, D.J. and Johnson, S. (1987), Regional Variations in Entrepreneurship in the U.K., Scottish Journal of Political Economy, 34, 161-73.

Storey, D.J. and. Jones, A.M (1987), New Firm Formation - A Labor Market Approach to Industrial Entry, Scottish Journal of Political Economy, 34, 37-51.

Sutton, J. (1991), Sunk Costs and Market Structure, Cambridge (Mass.), MIT Press.

Sutton, J. (1997), Gibrat's Legacy, Journal of Economic Literature, 35, 40-59.

Taylor, M. (1999), Self-employment and Windfall Gains in Britain: Evidence from Panel Data, CEPR Discussion Paper, No. 2084, London, CEPR. 
Taymaz, E. and Köksal, M. Y. (2006), Entrepreneurship, Start-up Size and Selection: Why do Small Entrepreneurs Fail?, forthcoming in Ekonomiaz: Basque Economics Journal.

Thurik, A.R. (2003), Entrepreneurship and Unemployment in the UK, Scottish Journal of Political Economy, 50, 264-90.

Van Praag, C.M. (1999), Some Classic Views on Entrepreneurship, De Economist, 147, 311-335.

Van Stel, A.J., Carree, M. and Thurik, A.R. (2005), The Effect of Entrepreneurial Activity on National Economic Growth, Small Business Economics, 24, 311-21.

Varga, A. and Schalk, J (2004), Knowledge Spillovers, Agglomeration and Macroeconomic Growth: An Empirical Approach, Regional Studies, 38, 977-89.

Vivarelli, M. (1991), The Birth of New Enterprises, Small Business Economics, 3, 215-23.

Vivarelli, M. (2004), Are All the Potential Entrepreneurs So Good?, Small Business Economics, 23, 41-49.

Vivarelli, M. (2006), Entry and Post-Entry Performance of Newborn Firms, London, Routledge.

Vivarelli, M. and Audretsch, D.B. (1998), The Link between the Entry Decision and Post-entry Performance: Evidence from Italy, Industrial and Corporate Change, 7, 485-500.

Wagner, J. (2003), Testing Lazear's Jack-of-all-trades View of Entrepreneurship with German Microdata, Applied Economics Letters, 10, 687-89.

Wennekers, S., van Stel, A.J., Thurik, A.R. and Reynolds, P.D. (2005), Nascent Entrepreneurship and the Level of Economic Development, Small Business Economics, 24, 293-309.

Winter, S.G. (1991), On Coase, Competence, and the Corporation, in Williamson, O.E. and Winter, S.G. (eds.), The Nature of the Firm: Origins, Evolution and Development, Oxford, Oxford University Press, 179-95.

Xu, B. (1998), A Reestimation of the Evans-Jovanovic Entrepreneurial Choice Model, Economics Letters, 58, 91-95.

Young, P. (2006), The Spread of Innovations Within Groups, Department of Economics, Johns Hopkins University, Baltimore (MD), http://www.econ.jhu.edu/People/Young/.

Zacharakis, A.L., Bygrave, W.D. and Shepherd, D.A. (2000), Global Entrepreneurship Monitor. National Entrepreneurship Assessment: United States of America, 2000 Executive Report, Babson Park (Mass), Babson College. 